\title{
The Relation between Fat Phobia and Body Image Perception and Their Effects on Healthy Lifestyle Behaviors
}

\section{Kilofobi ile Beden İmajı Algısı Arasındaki İlişki ve Sağlıklı Yaşam Tarzı Davranışları Üzerindeki Etkileri}

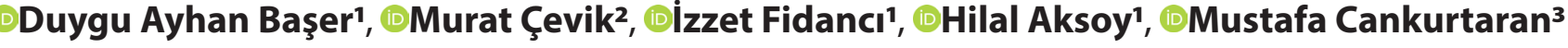 \\ 'Hacettepe University School of Medicine Department of Family Medicine, Ankara, Turkey \\ ${ }^{2}$ Güdül Family Health Center, Ankara, Turkey \\ ${ }^{3}$ Hacettepe University School of Medicine Department of Internal Medicine, Division of Geriatrics, Ankara, Turkey
}

\begin{abstract}
Aim: The aim of this study was to evaluate the relationship between fat phobia, body image perception and theirs affects on healthy lifestyle behaviors.

Material and Method: This descriptive study consisted of 548 individuals. Data was collected by using the sociodemographic form, Fat Phobia Scale (FPS) and Body Perception Scale (BPS).

Results: FPS mean score of participants was $2.88 \pm 0.35$, BPS mean score was $139.59 \pm 28.77$. Participants who do regular physical activity, have regular diet, pay attention to the content of meal and constantly dieters were had higher BPS and who do regular physical activity, don't regularly consume three main meals had higher FPS scores.
\end{abstract}

Conclusion: Determining fat phobia levels and body image perceptions would be beneficial at giving healthy lifestyle behavior counseling to people by being more careful in practice.

Keywords: Fat phobia, body image perception, healthy lifestyle
Öz

Amaç: Bu çalışmanın amacı, kilofobi, vücut imajı algısı ve bunların sağılılı yaşam tarzı davranışları üzerindeki etkileri arasındaki ilişkiyi değerlendirmektir.

Gereç ve Yöntem: Tanımlayıcı tipteki bu çalışma 548 kişiden oluşmuştur. Veriler, sosyodemografik form, Kilofobi Ölçeği (KFÖ) ve Vücut Algı Ölçeği (VAÖ) kullanılarak toplanmıştır.

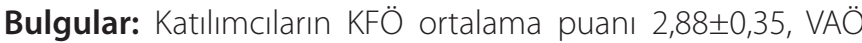
ortalama puanı 139,59 $\pm 28,77$ idi. Düzenli fiziksel aktivite yapan, düzenli diyet yapan, öğün içeriğine dikkat eden ve sürekli diyet yapanların VAÖ puanları daha yüksek, düzenli fiziksel aktivite yapan, düzenli olarak üç ana öğün tüketmeyen katılımcıların KFÖ puanları daha yüksekti.

Sonuç: Kişilerin kilofobi düzeylerini ve vücut imajı algılarını belirlemek, pratikte daha dikkatli davranarak insanlara sağlıklı yaşam tarzı davranış danışmanlığı vermede faydalı olacaktır.

Anahtar Kelimeler: Kilofobi, beden imajı algısı, sağlıklı yaşam tarzl 


\section{INTRODUCTION}

Negative attitudes towards people with high body weight or obesity is defined as "Fat phobia". [1] These negative attitudes towards people with excess body weight are not only consciously displayed, but they can also occur unconsciously and due to prejudice. This situation arises because more people think that the weight can be controlled and the problem of being overweight is due to the person with excess body weight. ${ }^{[2]}$

Body perception is the shape of the individual's own body shaped in his/her mind, in other words, the individual evaluates the parts of his/her own body and the functions of these parts positively or negatively. ${ }^{[3]}$ With the influence of the media, the importance given to being beautiful/ handsome and having an ideal body is increasing. ${ }^{[4]}$ This perception increases the likelihood of many problems in individuals, both emotionally and physically.

Healthy lifestyle behaviors are defined as controlling all behaviors that affect an individual's health and choosing behaviors appropriate to his/her health status in organizing daily activities. These behaviors include behaviors that increase the individual's well-being and provide selfimprovement. $^{[5]}$ Behaviors such as enough and regular exercise, a balanced diet, smoking, alcohol and substance abuse, coping with communication problems, health responsibility and stress management are effective in improving health. ${ }^{[5,6]}$ Also people apply healthy lifestyle behaviors to improve their bodies and prevent obesity. Perceptual measures pertain to the way in which people perceive their body, in particular their body size and the major perceptual measure is the healthy lifestyle behaviors.

In the literature, fat phobic people were described as mostly women, normal or under-normal weight and young ${ }^{[2]}$ and this profile was same with people who apply healthy lifestyle behaviors. $^{[5,6]}$ No publications were found in the literature on the perceptions of individuals (fat phobic) who have prejudices and negative attitudes towards obese/overweight individuals about their own bodies and their healthy lifestyle behaviors as a precaution to prevent weight gain. The aim of this study is to evaluate the relationship between fat phobia and body image perception and theirs effects on lifestyle behaviors.

\section{MATERIAL AND METHOD}

This study was conducted with observational methods. The universe of the research consists of individuals who can use smart phones. The sample calculation was not made in the study, and the number of patients who filled the questionnaire form between the specified dates and met the inclusion criteria constituted the sample of the study. In the study, being over the age of 18 , not having a coordination problem and accepting to participate in the study were evaluated as the inclusion criteria. Verbal and written consent was obtained from those who accepted to participate in the study.

The study was conducted between 15 August 202001 October 2020. The data were collected on the web (Facebook, Whats up) after the ethics committee was received with a questionnaire prepared by the researchers. The questionare form was shared on the specified platforms on the web. Inclusion criteria and consent form were specified at the beginning of the questionnaire. Those who marked the consent form as "I accept" were able to access the questionnaire. There is no one marking "I do not agree to participate in the study" in the analysis. During the analysis of the questions, those under the age of 18 were excluded from the study. The e-questionnaire form developed by the researchers was shared 10 times on the web.

Participants were administered a questionnaire consisting of eleven questions evaluating their sociodemographic informations and seven questions were about the healthy lifestyle behaviors. Fat Phobia Scale (FPS) was used to determine the level of participants' fat phobia and The Body Perception Scale (BPS) was used to determine the level of satisfaction of people with various parts of their bodies and various body functions.

Fat phobia scale: The Fat Phobia Scale (FPS) consists of 14 pairs of adjectives, one positive and one negative, that characterize overweight individuals, and the participants score overweight individuals between these adjectives 1-5 according to the degree of qualification. ${ }^{[7]}$ Turkish version of the scale was made by Kocak et al. in 2005 and Cronbach's Alpha for Turkish Fat Phobia short form of the scale was found to be $0.82 .{ }^{[8]}$ The scoring of the FBS is calculated by dividing the total score obtained from 14 items by the number of items. High scores between 1-5 indicate that individuals are more fat phobic and lower scores are less fat phobic.

Body Perception Scale: The Body Perception Scale (BPS) aims to measure how satisfied people are with various parts of their bodies and various body functions. ${ }^{[9]}$ Cronbach found the alpha internal consistency coefficient as $0.91(p<0.01)$. The scale includes 40 items, and each item is related to an organ or a part of the body (such as arm, leg, face) or a function (such as sexual activity level). Each item scores from 1 to 5 , and it is considered to be "I like it very much" (1 point), "I quite like it" (2 points), "I am indecisive" (3 points), "I do not like" (4 points) and "Not at all. There are response options such as "I don't like" (5 points). The total score of the non-cutoff scale ranges from 40 to 200. High scores indicate higher levels of dissatisfaction.

\section{Statistical Method}

Data were analyzed with IBM SPSS V23. Compliance with normal distribution was examined by Kolmogorov Smirnov and Shapiro Wilk. In the evaluation of the data, mean, standard deviation for continuous variables and frequency table for qualitative data were used. Data that did not show normal distribution were given as median (minimum 
- maximum). Chi-square test was used to investigate the relationship between qualitative data. The Kruskal Wallis test was used to compare data that did not show normal distribution. The relationship between variables was analyzed using Spearman correlation analysis. The level of significance was taken as $\mathrm{p}<0.050$.

\section{RESULTS}

Of the participants ( $\mathrm{N}=548), 322(58.8 \%)$ were female, 492 $(89.8 \%)$ were graduated from university, $446(81.4 \%)$ had an occupation and 310 (56.6\%)'s job was health-related, 211 $(38.5 \%)$ had more than one child. The mean of the age was $39.14 \pm 10.74$ years $(\min =18 ; \max =74)$; the mean of the BMI was $25.27 \pm 4.35 \mathrm{~kg} / \mathrm{m}^{2}(\min =16.67 ; \max =43.11) .271(49.5 \%)$ of participants had normal BMI (18.5-24.9), 363 (66.2\%) of them had any chronic disease, $456(83.2 \%)^{\prime}$ thought that they were healthier (Table 1).

Table 1. Descriptive characteristics of participants

Number (n) Percent (\%)

\begin{tabular}{|c|c|c|}
\hline & & \\
\hline $\begin{array}{l}\text { Gender } \\
\text { Male } \\
\text { Female }\end{array}$ & $\begin{array}{l}226 \\
322\end{array}$ & $\begin{array}{l}41.2 \\
58.8\end{array}$ \\
\hline $\begin{array}{l}\text { Education status } \\
\text { Primary / Secondary school graduate } \\
\text { University graduate }\end{array}$ & $\begin{array}{l}56 \\
492\end{array}$ & $\begin{array}{l}10.2 \\
89.8\end{array}$ \\
\hline $\begin{array}{l}\text { Working status } \\
\text { Working } \\
\text { Not working }\end{array}$ & $\begin{array}{l}102 \\
446\end{array}$ & $\begin{array}{l}18.6 \\
81.4\end{array}$ \\
\hline \multicolumn{3}{|c|}{ Profession (total number of as a student/as a worker) } \\
\hline $\begin{array}{l}\text { Health personnel } \\
\text { Other }\end{array}$ & $\begin{array}{l}310 \\
238\end{array}$ & $\begin{array}{l}56.6 \\
43.4\end{array}$ \\
\hline $\begin{array}{l}\text { Number of child } \\
0 \\
1 \\
2 \leq\end{array}$ & $\begin{array}{l}191 \\
146 \\
211\end{array}$ & $\begin{array}{l}34.9 \\
26.6 \\
38.5\end{array}$ \\
\hline $\begin{array}{l}\text { Economical status } \\
\text { Upper } \\
\text { Medium } \\
\text { Lower Intermediate }\end{array}$ & $\begin{array}{l}86 \\
422 \\
40\end{array}$ & $\begin{array}{l}15.7 \\
77.0 \\
7.3\end{array}$ \\
\hline $\begin{array}{l}\text { BMI } \\
\text { Below normal } \\
\text { Normal } \\
\text { Overweight } \\
\text { Obese }\end{array}$ & $\begin{array}{c}11 \\
271 \\
187 \\
79\end{array}$ & $\begin{array}{c}2.0 \\
49.5 \\
34.1 \\
14.4\end{array}$ \\
\hline $\begin{array}{l}\text { Presence of health problems } \\
\text { Yes } \\
\text { No }\end{array}$ & $\begin{array}{l}185 \\
363 \\
\end{array}$ & $\begin{array}{l}33.8 \\
66.2 \\
\end{array}$ \\
\hline $\begin{array}{l}\text { Thought about health status of him/l } \\
\text { Yes I'm healthy } \\
\text { No I don't feel healthy }\end{array}$ & $\begin{array}{l}456 \\
92\end{array}$ & $\begin{array}{l}83.2 \\
16.8\end{array}$ \\
\hline
\end{tabular}

$57.5 \%(n=315)$ of patients were said that their approach to weight gain changes according to their mood. Graphic 1 showed the thoughts of participants on weight gain.

FPS mean score of participants was 2.88 \pm 0.35 ( $\mathrm{min}=1.43$, $\max =4.43$ ), BPS mean score was $139.59 \pm 28.77$ ( $\min =45$, $\max =200$ ) (Table 2).

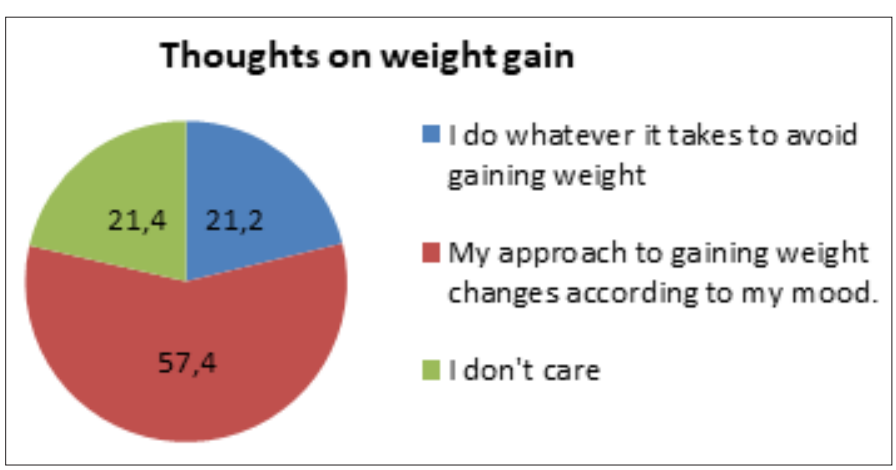

Graphic 1. The thoughts of participants on weight gain

\begin{tabular}{lcc}
\hline Table 2. Mean scores on FPS, BPS & \\
Scale & Mean \pm SD (min-max) & Range interval \\
\hline FPS & $2.88 \pm 0.35$ & $1.43-4.43$ \\
BPS & $139.59 \pm 28.77$ & $45-200$ \\
\hline
\end{tabular}

FPS scores of the females $(p=0.001)$, unemployed $(p=0.030)$ and non-health worker people $(p=0.017)$ were higher compared to the others (Table 3 ). While the BPS scores of people with upper economic status $(p=0.014)$, normal and under-normal weighted $(p<0,000)$, people who had not any chronic disease $(p=0.001)$ and people who thought that they were healthier $(p<0.000)$ were higher compared to the others (Table 3). People whose approach to weight gain varies according to their mood had lower BPS scores $(p=0.011)$ and people who do whatever it takes to avoid gaining weight had higher FPS scores ( $p=0.017)$ (Table 3).

The relationship of the healthy life style behaviors of participants and fat phobia and body perception scores were presented at Table 4. People who do regular physical activity had higher FPS and BPS scores. Participants who had regular diet and who pay attention to the content of meal and constantly dieters were had higher BPS scores and who don't regularly consume three main meals had higher FPS scores.

There was a low negative correlation between BPS scores and age $(p=0.018 ; r=-0.101)$; there was no correlation between FPS scale and BPS scores (Table 5).

Table 5. Pearson correlation between FPS, BPS and age

\begin{tabular}{lcccc} 
& & Age & FPS & BPS \\
\hline \multirow{3}{*}{ Age } & $\mathrm{r}$ & 1 & -.013 & $-.101^{*}$ \\
& $\mathrm{p}$ & & .757 & .018 \\
& $\mathrm{~N}$ & 548 & 540 & 548 \\
\hline \multirow{3}{*}{ FPS } & $\mathrm{r}$ & -.013 & 1 & -.022 \\
& $\mathrm{P}$ & .757 & & .615 \\
& $\mathrm{~N}$ & 540 & 540 & 540 \\
\hline \multirow{3}{*}{ BPS } & $\mathrm{r}$ & $-.101^{*}$ & -.022 & 1 \\
& $\mathrm{P}$ & .018 & .615 & \\
& $\mathrm{~N}$ & 548 & 540 & 548 \\
\hline *. Correlation is significant at the 0.05 level (2-taild). & &
\end{tabular}




\begin{tabular}{|c|c|c|c|c|}
\hline & \multicolumn{2}{|c|}{ Fat phobia scores } & \multicolumn{2}{|c|}{ Body perception scores } \\
\hline & Mean $\pm S D$ (min-max) & $\mathbf{p}$ & Mean $\pm S D(\min -\max )$ & $\mathbf{p}$ \\
\hline $\begin{array}{l}\text { Gender } \\
\text { Male } \\
\text { Female }\end{array}$ & $\begin{array}{l}2.82 \pm 0.32(1.43-3.29) \\
2.93 \pm 0.35(2.14-4.43)\end{array}$ & 0.001 & $\begin{array}{l}135.46 \pm 35.33(45-187) \\
140.97 \pm 28.37(50-200)\end{array}$ & 0.396 \\
\hline $\begin{array}{l}\text { Education status } \\
\text { Primary / Secondary school graduate } \\
\text { University graduate }\end{array}$ & $\begin{array}{l}2.95 \pm 0.38(2.14-4.14) \\
2.87 \pm 0.35(1.43-4.43)\end{array}$ & 0.119 & $\begin{array}{l}131.46 \pm 38.37(50-187) \\
140.52 \pm 27.37(45-200)\end{array}$ & 0.325 \\
\hline $\begin{array}{l}\text { Working status } \\
\text { Working } \\
\text { Not working }\end{array}$ & $\begin{array}{l}2.86 \pm 0.32(2.14-4.36) \\
2.97 \pm 0.48(1.43-4.43)\end{array}$ & 0.030 & $\begin{array}{c}139.89 \pm 28.77(45-200) \\
138 \pm 31.83(51-191)\end{array}$ & 0.986 \\
\hline $\begin{array}{l}\text { Profession } \\
\text { Health professional } \\
\text { Other }\end{array}$ & $\begin{array}{l}2.86 \pm 0.34(2.14-4.36) \\
2.91 \pm 0.37(1.43-4.43)\end{array}$ & 0.017 & $\begin{array}{l}141.43 \pm 26.31(45-200) \\
137.19 \pm 31.59(50-195) \\
\end{array}$ & 0.508 \\
\hline $\begin{array}{l}\text { Number of child } \\
0 \\
1 \\
2 \leq\end{array}$ & $\begin{array}{l}2.93 \pm 0.33(1.43-4.14) \\
2.82 \pm 0.29(2.14-4.00) \\
2.88 \pm 0.40(2.14-4.43)\end{array}$ & 0.336 & $\begin{array}{l}142.38 \pm 26.77(51-200) \\
139.97 \pm 26.08(45-200) \\
136.80 \pm 32.00(50-199)\end{array}$ & 0.609 \\
\hline $\begin{array}{l}\text { Economical status } \\
\text { Upper } \\
\text { Medium } \\
\text { Lower Intermediate }\end{array}$ & $\begin{array}{l}2.82 \pm 0.26(2.21-3.43) \\
2.90 \pm 0.37(1.43-4.43) \\
2.87 \pm 0.31(2.14-3.79)\end{array}$ & 0.307 & $\begin{array}{l}147.87 \pm 24.37(61-200) \\
138.63 \pm 28.77(45-200) \\
131.87 \pm 34.08(64-190)\end{array}$ & 0.014 \\
\hline $\begin{array}{l}\text { BMI*** } \\
\text { Below normal } \\
\text { Normal } \\
\text { Overweight } \\
\text { Obese }\end{array}$ & $\begin{array}{l}2.96 \pm 0.20(2.71-3.29) \\
2.88 \pm 0.36(1.43-4.43) \\
2.87 \pm 0.32(2.14-4.00) \\
2.89 \pm 0.45(2.14-4.36)\end{array}$ & 0.283 & $\begin{array}{l}149.63 \pm 32.42(93-187) \\
144.31 \pm 27.11(45-200) \\
135.68 \pm 27.84(64-199) \\
131.27 \pm 32.86(51-195)\end{array}$ & 0.000 \\
\hline $\begin{array}{l}\text { Presence of health problems } \\
\text { Yes } \\
\text { No }\end{array}$ & $\begin{array}{l}2.86 \pm 0.36(1.43-4.14) \\
2.89 \pm 0.35(2.14-4.43)\end{array}$ & 0.581 & $\begin{array}{l}134.97 \pm 29.05(50-195) \\
141.95 \pm 28.38(45-200)\end{array}$ & 0.001 \\
\hline $\begin{array}{l}\text { Thought about health status of him/herself } \\
\text { Yes I'm healthy } \\
\text { No I don't feel healthy }\end{array}$ & $\begin{array}{l}2.88 \pm 0.34(2.14-4.43) \\
2.89 \pm 0.43(1.43-4.14)\end{array}$ & 0.553 & $\begin{array}{l}142.89 \pm 27.86(50-200) \\
122.22 \pm 27.75(45-195)\end{array}$ & 0.000 \\
\hline $\begin{array}{l}\text { Thoughts about weight gain } \\
\text { I do whatever it takes to avoid gaining weight } \\
\text { My approach to weight gain varies according to my mood. } \\
\text { I don't care }\end{array}$ & $\begin{array}{l}2.91 \pm 0.30(2.21-4.14) \\
2.86 \pm 0.37(2.14-4.43) \\
2.90 \pm 0.37(1.43-3.79)\end{array}$ & 0.011 & $\begin{array}{l}144.85 \pm 30.15(50-200) \\
138.47 \pm 26.99(45-195) \\
137.40 \pm 31.55(57-200)\end{array}$ & 0.017 \\
\hline $\begin{array}{l}\text { *** BMI } \\
\text { Below normal: BMI: }<18.5 \\
\text { Normal:BMI: } 18.5-24.9 \\
\text { Overweight:BMI: } 25-29.9 \\
\text { Obese:BMI: }>30\end{array}$ & & & & \\
\hline
\end{tabular}

Table 4. The relationship between the healthy life style behaviours of participants and FPS and BPS

\begin{tabular}{|c|c|c|c|c|}
\hline & \multicolumn{2}{|l|}{ FPS } & \multicolumn{2}{|l|}{ BPS } \\
\hline & Mean \pm SD (min-max) & $\mathbf{p}$ & Mean $\pm S D(\min -\max )$ & $\mathbf{p}$ \\
\hline $\begin{array}{l}\text { Smoking } \\
\text { Yes. I'm smoking } \\
\text { I left } \\
\text { I've never used }\end{array}$ & $\begin{array}{l}2.88 \pm 0.39(1.43-4.14) \\
2.96 \pm 0.44(2.14-4.43) \\
2.86 \pm 0.28(2.14-4.29)\end{array}$ & 0.355 & $\begin{array}{l}137.03 \pm 30.96(51-191) \\
138.55 \pm 27.18(67-190) \\
141.07 \pm 28.28(45-200)\end{array}$ & 0.334 \\
\hline $\begin{array}{l}\text { Alcohol } \\
\text { Yes I'm using } \\
\text { l left } \\
\text { I've never used }\end{array}$ & $\begin{array}{l}2.92 \pm 0.32(1.43-4.43) \\
2.86 \pm 0.39(2.14-4.29) \\
2.86 \pm 0.32(2.14-4.36)\end{array}$ & 0.122 & $\begin{array}{l}140.26 \pm 28.54(45-195) \\
143.86 \pm 24.74(77-199) \\
138.47 \pm 29.53(45-200)\end{array}$ & 0.479 \\
\hline $\begin{array}{l}\text { Regular physical activity } \\
\text { Yes } \\
\text { No }\end{array}$ & $\begin{array}{l}2.95 \pm 0.37(2.29-4.43) \\
2.86 \pm 0.34(1.43-4.14)\end{array}$ & 0.027 & $\begin{array}{l}151.52 \pm 26.87(45-200) \\
135.18 \pm 28.23(51-200)\end{array}$ & 0.000 \\
\hline $\begin{array}{l}\text { Regular diet } \\
\text { Yes } \\
\text { No }\end{array}$ & $\begin{array}{l}2.87 \pm 0.34(2.14-4.43) \\
2.91 \pm 0.39(1.43-4.29)\end{array}$ & 0.334 & $\begin{array}{l}142.33 \pm 27.73(45-200) \\
133.44 \pm 30.17(51-190)\end{array}$ & 0.001 \\
\hline $\begin{array}{l}\text { Paying attention to the contents of the meal in the diet } \\
\text { Yes } \\
\text { No }\end{array}$ & $\begin{array}{l}2.87 \pm 0.35(2.14-4.43) \\
2.89 \pm 0.36(1.43-4.29)\end{array}$ & 0.254 & $\begin{array}{l}145.63 \pm 26.25(45-200) \\
131.11 \pm 30.05(51-200)\end{array}$ & 0.000 \\
\hline $\begin{array}{l}\text { Regularly consume three main meals } \\
\text { Yes } \\
\text { No }\end{array}$ & $\begin{array}{l}2.84 \pm 0.32(2.14-4.36) \\
2.92 \pm 0.38(1.43-4.43)\end{array}$ & 0.007 & $\begin{array}{l}140.62 \pm 28.34(45-195) \\
138.68 \pm 29.17(51-200)\end{array}$ & 0.355 \\
\hline $\begin{array}{l}\text { Diet program applied } \\
\text { Yes. I constantly apply } \\
\text { Yes. I apply occasionally } \\
\text { No. I have never been on a diet }\end{array}$ & $\begin{array}{l}2.89 \pm 0.32(2.29-3.93) \\
2.87 \pm 0.32(2.14-4.36) \\
2.89 \pm 0.39(1.43-4.43)\end{array}$ & 0.947 & $\begin{array}{l}152.41 \pm 25.65(103-200) \\
136.51 \pm 29.03(45-199) \\
140.45 \pm 28.46(51-200)\end{array}$ & 0.018 \\
\hline
\end{tabular}




\section{DISCUSSION}

In the literature, the fat phobic people were described as mostly women, normal or under-normal weight and young and also people with this profile were satisfied from their body. ${ }^{[2]}$ However, we did not come across any publication which evaluates this relationship. First aim of this study was to evaluate this relationship. However, this study showed that, there was no relation between body satisfaction and fat phobia.

In analyses we found that several factors affected both body satisfaction and fat phobia. Fat phobic behaviors and negative attitudes toward obese/overweighed individuals were observed in several researches ${ }^{[1,2,10-13]}$ and range of FPS mean score was changed between 3.25-3.72. ${ }^{[1,2,11-14]}$ In the present study, it was determined that FPS mean score of the participants was $2.88 \pm 0.35$. Considering that higher scores of FPS indicate more fat phobic features, our participants were exhibited less fat phobic features than other studies' participants. The major reason of this was that the vast majority of studies were conducted on students and younger adults; however, there was no age limitation in our study. Although age could not have a significant effect on fat phobia in our study; the lower fat phobia scores in our study suggested that young people could be more sensitive on this issue when compared to other studies. In this study we found that; women, unemployed and non-health worker participants were fatter phobic than others. Participants who do whatever it takes to avoid gaining weight were more fat phobic than others. The effect of gender on fat phobia has been stated in most studies. ${ }^{[1,2,13-15]}$ Especially the effect of media on this issue (slim, weak, and tall women highlighted by the media are considered beautiful) could lead women to fat phobia. ${ }^{[1]}$ There was no study evaluating the effect of sociodemographic characteristics on fat phobia in details and the samples of previous studies were composed of usually from students. So the results about working status and weight loss effort were specific to this study.

In the present study, it was determined that BPS mean score was $139.59 \pm 28.77$ and high scores of BPS indicate higher levels of body dissatisfaction. When compared with other studies in the literature, it was seen that the BPS mean scores in our study were lower and this means that body satisfaction of participants were higher. ${ }^{[4]}$ Participants who have not chronically disease, who think they were healthier, who have high socioeconomic status and low BMl were more dissatisfied than others. Body dissatisfaction increased with the decrease in age. People whose approach to gaining weight changes according to their mood were more satisfied from their body than others. When we look at the profile of those who are dissatisfied with their body in our study, we saw that they were younger, healthier, weaker and financially welloff. Investigating the underlying causes of these interesting results is very important in terms of measures to be taken in this regard.
Secondary aim of our study was to evaluate the relationship between the fat phobia and healthy lifestyle behaviors. In our study, physical activity status, nutritional status, smoking and alcohol use status were evaluated as healthy lifestyle behaviors. And people who regularly do physical activity were found to be more fat phobic and more dissatisfied from their body. In contrast to our study, Moustafa et al. found the significant positive association between "physical activity" and "body satisfaction perception". ${ }^{[4]}$ In reverse, it was thought that those who exercise more regularly may have a negative attitude towards weight/ being overweight and they may be tend to exercise in order to be satisfied from their bodies more. In addition, we found that people who eat more regularly and pay more attention to the content of their food, dissatisfied from their bodies more and those who do not consume regular three meals were more fat phobic. The results about body satisfaction were in accordance with both physical activity status and nutritional status. It was seen that those who make more effort to lose weight or pay more attention to their weight were not satisfied with their bodies. In previous studies which were about healthy life style behaviors and body perception or fat phobia did not show any relationships between them. ${ }^{[1,4]}$

Literature has focused mainly on young adults fat phobia, body image and its perception; ${ }^{[1,12-15]}$ however our study sample included people from all age groups. This is the superior aspect of our work. Limitations of our study include its design, being cross-sectional. Thus the findings of this study may not be representative for the population.

\section{CONCLUSION}

As a conclusion the major hypothesis of study (there is a relationship between fat phobia and body satisfaction) was not confirmed. However; many factors have been identified that were related to these two important body perception problems. According to the results of the study, counseling can be given to people with the specified profile in our study by being more careful in practice in order not to develop unhealthy lifestyle behaviors.

\section{ETHICAL DECLARATIONS}

Ethics Committee Approval: Ethic committee approval was from Hacettepe University Non Invasive Studies Ethics Committee, 09/06/2020 and GO20/494).

Informed Consent: Written consent was obtained from all patients who participated in the study and their relatives.

Referee Evaluation Process: Externally peer-reviewed.

Conflict of Interest Statement: The author(s) declared no potential conflicts of interest with respect to the research, authorship, and/or publication of this article.

Financial Disclosure: The authors declared that this study has received no financial support. 


\section{REFERENCES}

1. Cetinkaya S, Sert H. Sakarya University students' fat phobia levels and attitudes towards obese individuals and their correlation with healthy lifestyle behaviors: Knowledge, attitude and practice (KAP) study. JPMA. 2018; 68 (9): 1358-62

2. Akyol B, Soğut K, Konar N. Canpolat, B. The Relationship between Fat phobia and Exercise Habits in Sedentary Women with Visually Impaired. Gaziantep University. Journal of Sport Sciences. 2018; 3(3): 102-10.

3. Grilo CM, Ivezaj V, Lydecker JA, White MA. Toward an understanding of the distinctiveness of body-image constructs in persons categorized with overweight/obesity, bulimia nervosa, and binge-eating disorder. J Psychosom Res. 2019;126:109757.

4. Moustafa S, Tawbe Z, Daouk SF, et al. Body Image Perception in Association with Healthy Lifestyle Behaviour's in Lebanese Men and Women. International Journal of School and Cognitive Psychology. 2017; 04.

5. Austen R. Anderson, Blaine J. Fowers. Lifestyle behaviors, psychological distress, and well-being: A daily diary study, Social Science \& Medicine. 2020; 263:113263.

6. Chevance G, Golaszewski NM, Baretta D, et al. Modeling multiple health behavior change with network analyses: results from a one-year study conducted among overweight and obese adults. J. Behav. Med. 2020; 43:254-61.

7. Bacon JG, Scheltema KE, Robinson BE. Fat phobia scale revisited: the short form. International Journal of Obesity, 2001; 25: 252-257

8. Koçak $S$, Saraç $L$, Hurmeriç I. Determining the relationships among body mass index, body composition and attitudes toward fat people, The ICHPER-SD Annivarsary World Congress, İstanbul, November 9-13. 2005.

9. Kundakçi AH. Üniversite Öğrencilerinin Yeme Tutumları, Benlik Algıları, Vücut Algısı ve Stres Belirtileri Açısından Karşılaştııııması. Yayınlanmamış Yüksek Lisans Tezi, Ankara Üniversitesi Sosyal Bilimler Enstitüsü, Ankara. 2005.

10. Darling R, Atav AS. Attitudes toward obese people: a comparative study of nursing, education, and social work students. J Prof Nurs. 2018; 35(2): 138-46.

11. Hemati N, Zokaei A. Attitudes and beliefs of nurses about excessive body weight and obesity. Soc Sci. 2016; 11(9): 2058-65.

12. Kadıoğlu B, Uncu F, Nazik F, et al. Fat phobia and Physical Activity Levels of Goren University Students of Two Different Universities. Adıyaman University Health Science Journa. 2015; 1(2): 77-86.

13. Sert H, Seven A, Çetinkaya S, Pelin M, Aygin D. Evaluation of prejudice against obesity in health high school students. Turk J Health Sci. 2016; 1(4): 9- 17.

14. Usta E, Bayram S, Altınbaş Akkaş Ö. Perceptions of nursing students about individuals with obesity problems: Belief, attitude, phobia. Perspect Psychiatr Care. 2020: 1- 9.

15. Hunter J, Rawlings-Anderson K, Lindsay T, Bowden T, Aitken LM. Exploring student nurses' attitudes towards those who are obese and whether these attitudes change following a simulated activity. Nurse Educ Today. 2018; 65: 225-31. 